\title{
Comparison of survival patterns of northern and southern genotypes of the North American tick Ixodes scapularis (Acari: Ixodidae) under northern and southern conditions
}

\author{
Howard S Ginsberg ${ }^{1,2^{*}}$, Eric L Rulison ${ }^{2,3}$, Alexandra Azevedo², Genevieve C Pang ${ }^{4}$, Isis M Kuczaj ${ }^{4}$, Jean I Tsao ${ }^{4}$ \\ and Roger A LeBrun ${ }^{2}$
}

\begin{abstract}
Background: Several investigators have reported genetic differences between northern and southern populations of Ixodes scapularis in North America, as well as differences in patterns of disease transmission. Ecological and behavioral correlates of these genetic differences, which might have implications for disease transmission, have not been reported. We compared survival of northern with that of southern genotypes under both northern and southern environmental conditions in laboratory trials.

Methods: Subadult I. scapularis from laboratory colonies that originated from adults collected from deer from several sites in the northeastern, north central, and southern U.S. were exposed to controlled conditions in environmental chambers. Northern and southern genotypes were exposed to light:dark and temperature conditions of northern and southern sites with controlled relative humidities, and mortality through time was recorded.

Results: Ticks from different geographical locations differed in survival patterns, with larvae from Wisconsin surviving longer than larvae from Massachusetts, South Carolina or Georgia, when held under the same conditions. In another experiment, larvae from Florida survived longer than larvae from Michigan. Therefore, survival patterns of regional genotypes did not follow a simple north-south gradient. The most consistent result was that larvae from all locations generally survived longer under northern conditions than under southern conditions.

Conclusions: Our results suggest that conditions in southern North America are less hospitable than in the north to populations of I. scapularis. Southern conditions might have resulted in ecological or behavioral adaptations that contribute to the relative rarity of I. scapularis borne diseases, such as Lyme borreliosis, in the southern compared to the northern United States.
\end{abstract}

Keywords: Ixodes scapularis, Survival, Northern genotypes, Southern genotypes, Geographical gradients

\section{Background}

The blacklegged tick, Ixodes scapularis Say (Acari: Ixodidae), is the primary North American vector of Borrelia burgdorferi Johnson, Schmid, Hyde, Steigerwalt \& Brenner, etiologic agent of Lyme disease, which is the most commonlyreported vector-borne disease in the United States [1]. This

\footnotetext{
*Correspondence: hginsberg@usgs.gov

'USGS Patuxent Wildlife Research Center, RI Field Station, Woodward Hall -

PSE, University of Rhode Island, Kingston, RI 02881, USA

2Department of Plant Sciences and Entomology, Woodward Hall, University

of Rhode Island, Kingston, RI 02881, USA

Full list of author information is available at the end of the article
}

tick is abundant in much of the northeastern, mid-Atlantic and north central United States, and is broadly distributed among the southeastern and south central states [2,3]. In this paper, "north" refers to the areas of eastern and central North America north of the mouth of the Chesapeake Bay ( $37^{\circ} \mathrm{N}$ latitude), while "south" refers to areas south of that latitude.

Population genetics studies in the past two decades have revealed a complex geographical pattern. One widespread I. scapularis lineage, the American Clade, predominates in the north and is also broadly distributed in southern states 
[4]. In the southern states however, there is greater genetic diversity, including several Southern clades that are rarely found in the north $[5,6]$. This pattern could have resulted from a founder effect during recent range expansion of $I$. scapularis following northward glacial recession $[7,8]$, or perhaps more recently, following broadscale landscape changes such as forest regrowth and expanding deer populations [9]. To date, the ecological characteristics of these various genetic groups have not been described.

Temperature and relative humidity $(\mathrm{RH})$ are fundamental environmental factors that influence tick survival [10-12]. Laboratory studies have confirmed the relationship between RH and survival of I. scapularis, and have estimated the critical equilibrium activity $\mathrm{RH}$ for nymphs $[13,14]$. Critical equilibrium activity $\mathrm{RH}$ is the level below which ticks lose water, thus possibly affecting survival [15]. Field studies indicate that survival in I. scapularis is greater in forested than in open habitats [16] and shows clear associations with temperature and humidity variables [17]. Furthermore, temperature and RH were related to summer activity in nymphal $I$. scapularis at a forest site in New Jersey [18], and influenced aspects of nymphal questing behavior in lab trials [19]. In view of the distributional pattern of genetic lineages of I. scapularis and the broad environmental differences between northern and southern regions, these results raise the question of whether the different genetic groups respond differently to the environmental conditions found in different regions of the eastern and central U.S.

In this study, we compare immature I. scapularis from northern genotypes (derived from adults collected at northeastern and north central locations) to ticks of southern genotypes (from multiple southern sites) in terms of survival under both northern and southern conditions of diurnal cycle and temperature, and at varying levels of relative humidity. We test three hypotheses about survival patterns of these ticks. The null hypothesis $\left(\boldsymbol{H}_{\boldsymbol{o}}\right)$ is that there is no difference in survival patterns between northern and southern ticks. The first alternative hypothesis $\left(\boldsymbol{H}_{\boldsymbol{1}}\right)$ is that the genetic groups are regionally adapted such that northern ticks survive longer than southern ticks under northern conditions, and southern ticks survive longer than northern ticks under southern conditions. The second alternative hypothesis $\left(H_{2}\right)$ is that the northern ticks, which come from the widely distributed northern genotypes, are hardier than the southern genotypes and survive longer than southern ticks under both northern and southern conditions. We assess variability of survival among different genotypes within as well as between different regions.

\section{Methods}

We tested the survival patterns of northern compared to southern genotypes of $I$. scapularis in three series of experiments (details below). The pilot study, experiment 1 , compared survival of both larvae and nymphs of $I$. scapularis from one northern site and one southern site, under both northern and southern temperature and daylength conditions, at both high and low relative humidities. Experiment two assessed variability within and between regions by testing survival of larvae from three different mothers from each site, and by testing ticks from additional northern and southern locations. We held larvae at high humidity for experiment 2 because that group showed a good spread in experiment 1. Experiment 3 tested larvae from three different mothers from each of two additional locations. We utilized an intermediate humidity level to determine whether the patterns observed in experiment 2 would differ at different humidities.

\section{Experiment 1}

Ixodes scapularis larvae were obtained from laboratory colonies maintained at Michigan State University. The northern colony originated from engorged adult ticks collected from white tailed deer in Wisconsin (hereafter, $\mathrm{WI}_{1}$ ). The southern colony originated from engorged adults collected from deer in South Carolina (SC). Offspring of those adults were reared (on mouse hosts) to adults that were fed on rabbits. All handling of animals in this study was performed in accordance with IACUC approval from Michigan State University (\# 06/12-103-00). Larvae that were the offspring from one adult of each clade were used in this study. Egg hatch for the northern ticks started on 7 February 2012, and egg hatch for the southern ticks started on 5 February 2012. The nymphs were derived from mouse-fed larvae, and individuals from both clades (originally from one southern female and four northern females) emerged from 19 April through 18 May 2012. The genetic characteristics of the colonies were determined at Georgia Southern University, using the clade classification developed by L. Beati, under which our northern ticks belonged to American Clade 1, and our southern ticks were Southern Clade 1 [6].

For the larval experiment, northern and southern conditions were based on light:dark and temperature cycles during the dates of peak larval activity in the north and south (based on 2011 field data). One Percival I-36LL environmental unit (Percival Scientific, Perry, IA) was set at northern conditions, based on average conditions at the Chatham weather station on Cape Cod, MA on 1 August (similar to those in Racine, WI), and a second environmental unit was set at southern conditions based on an Aiken, SC weather station on 15 June. Northern conditions were L:D 14.5:9.5 hrs, day $23.3^{\circ} \mathrm{C}$ : night $16.6^{\circ} \mathrm{C}$. Southern conditions were L:D 14.4:9.6 hrs, day $32.3^{\circ} \mathrm{C}$, night $18.3^{\circ} \mathrm{C}$. The chambers switched abruptly between day and night conditions. For the nymphal experiment, northern settings were based on Chatham conditions 
on 15 June (15.25:8.75 L:D, 19.4:12.2 $\left.{ }^{\circ} \mathrm{C}\right)$, and southern settings were based on Aiken conditions on 15 July (14.17:9.83 L:D, 34.4:20.5 ${ }^{\circ} \mathrm{C}$ ).

Within each environmental unit, two humidity chambers were maintained at high humidity (using deionized water) and two chambers at low humidity (using saturated $\mathrm{NaCl}$ solutions), to produce $\mathrm{RH}$ of about $90 \%$ and $75 \%$ in the two treatments [20]. These $\mathrm{RH}$ values were selected because the critical equilibrium activity $\mathrm{RH}$ for I. scapularis nymphs, below which survival is affected, is about $82-85 \%[13,14]$. Eight to ten plastic jars (3-dram snap-cap vials; IntraPac, Plattsburgh, NY) with screen tops were placed in each humid chamber, with an average of about 5 ticks per jar. This approach allowed observers to easily detect mortality of individual ticks in each jar, to count totals for each treatment, and to provide estimates of variability in mortality among jars. Ticks of the two clades were randomly assigned to treatments, such that ticks from each clade were placed in high and low RH chambers under northern and southern conditions. The larval trial was run on 21-26 May, and the nymphal trial on 11-17 June 2012. Survival was determined by tapping each jar on the tabletop, breathing through the screen top, and then observing under a dissecting microscope for evidence of any movement. The numbers of live and dead ticks were recorded. Observations were made every eight hours for 48 hours after initial setup, and every 24 hours thereafter. Temperature and humidity were recorded before each reading using Fisher Scientific Traceable Humidity/Temperature Pens (Control Company, Friendswood, TX) that were maintained within each chamber.

Survival through time was analyzed by comparing cumulative mortality between treatments using KolmogorovSmirnov two-sample tests [21], which assess whether the point of greatest difference between two cumulative distributions is large enough to consider the distributions different. Two-tailed tests were used to test the null hypothesis (no difference between treatments), and one-tailed tests were used to test the alternative hypotheses (survival was greater in one treatment than another).

\section{Experiment 2}

We studied variability in survival of immature I. scapularis within and between geographical regions by testing larvae from three different mothers from each of three different locales. We used larvae at high humidity because this level provided a broad spread in the results of Experiment 1 (Figure 1). The larvae hatched in the lab at Michigan State University from eggs laid by engorged females that had been collected from white tailed deer at check stations in Fort McCoy, Wisconsin $\left(\mathrm{WI}_{2}\right)$, Middleboro, Massachusetts (MA), and Bulloch County, Georgia (GA).
Egg hatch started from 20-28 December 2012 for the GA ticks, but from 29 January - 11 February 2013 for the $\mathrm{WI}_{2}$ and $\mathrm{MA}$ ticks, so to insure that the larvae were roughly the same age, we started the survival trials for the GA larvae on 8 April, and for the $\mathrm{WI}_{2}$ and MA larvae on 23 May 2013. Larvae were held at high humidity, $20-24^{\circ} \mathrm{C}$ and ambient light/dark before the survival trials. We placed a clump of approximately 10 larvae in each screentop jar, and randomly placed jars into humid chambers and treatments (three chambers each in northern and southern treatments) such that there were three jars with larvae from each mother in each chamber. Northern and southern conditions were as in Experiment 1. Jars were examined for tick survival every 12 hours for the first 48 hours, daily for the next 6 days, every third day for the following 2 readings, and weekly for the following 2 weeks, for a total of 28 days (672 hours).

Survival was compared by analyzing the proportion alive in each jar at the end of the experiment using ANOVA with arcsine transformed proportions (SAS, version 9.3, GLM subprogram). The model included terms for northern vs. southern conditions, region (=state) of origin, clutch (larvae from each of the three females) nested within region, and interaction of $\mathrm{N} / \mathrm{S}$ conditions with region of origin.

\section{Experiment 3}

We assessed the generality of results from the previous experiments by testing survival of larvae from two additional locales and holding them at intermediate RH levels (attained using saturated $\mathrm{KCl}$ solutions in the humid chambers). The northern larvae came from three laboratory rabbit-fed females from Michigan (MI), and the southern larvae were from three laboratory rabbit-fed females from northern Florida (FL). FL egg hatch was from 1-17 May, while MI egg hatch was from 21 June - 4 July, so to insure that the larvae were roughly the same age, we started the FL survival trial on 19 July and the MI survival trial on 12 September 2013. Larvae were placed in screentop jars within humid chambers as in Experiment 2, and jars were examined for tick survival according to the same schedule. Data were analyzed as in Experiment 2.

\section{Results}

\section{Experiment 1}

Larvae. Daytime humidity averaged about $91 \%$ in the high $\mathrm{RH}$ chambers and $74 \%$ in the low $\mathrm{RH}$ chambers (Table 1). At least some larvae survived in all treatments under high $\mathrm{RH}$ conditions, but not under low $\mathrm{RH}$ (Figure 1). Survival differed significantly between $\mathrm{WI}_{1}$ and SC larvae under conditions of both high $\mathrm{RH}$ (Kolmogorov-Smirnov Test, 2-tailed, $n_{A 1}=94, n_{S 1}=88$, $\boldsymbol{D}=0.337, \boldsymbol{p}<0.001)$ and low RH $\left(n_{A 1}=68, n_{S 1}=72\right.$, $D=0.343, \mathrm{p}<0.001)$. Therefore, the null hypothesis is 

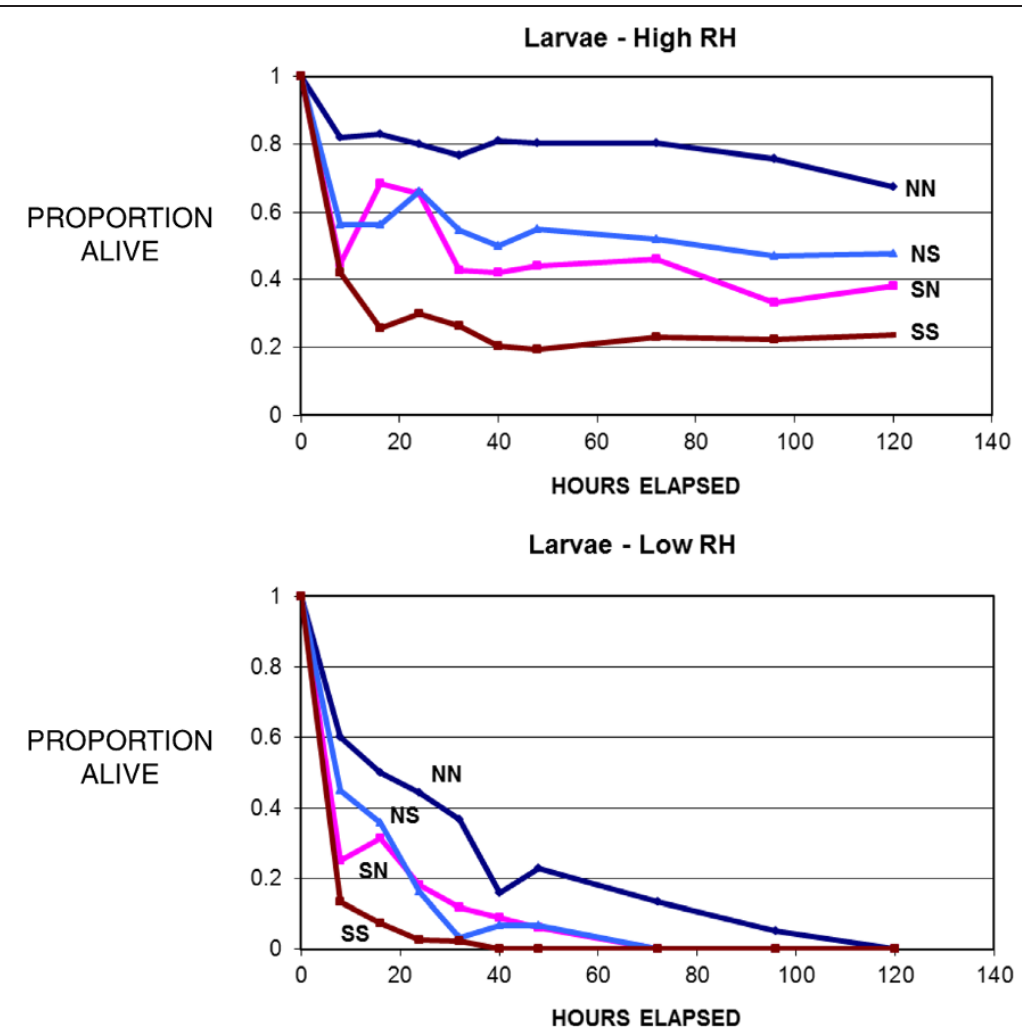

Figure 1 Survival of Ixodes scapularis larvae under conditions of high and low relative humidity. NN = northern (WI) ticks under northern conditions; NS = northern ticks under southern conditions; SN = southern (SC) ticks under northern conditions; SS = southern ticks under southern conditions.

rejected. $\boldsymbol{H}_{\boldsymbol{1}}$ is also rejected, because survival of SC larvae was not greater than that of $\mathrm{WI}_{1}$ larvae under southern conditions (Figure 1). In fact, $\mathrm{WI}_{1}$ survival was consistently higher than that of SC larvae under both high $\mathrm{RH}$ (Kolmogorov-Smirnov 1-tailed test, $\chi^{2}=20.621, \boldsymbol{p}<0.001$ ) and low RH $\left(\chi^{2}=16.443, \boldsymbol{p}<0.001\right)$ conditions (Figure 1 ). These results support $\boldsymbol{H}_{2}$, that the broader ranging $\mathrm{WI}_{1}$ (American Clade) larvae are generally hardier than SC (Southern Clade) larvae. The apparent upward "blips" in some of the survival curves presumably resulted from ticks that were immobile during a reading, but not dead, and were active during a subsequent reading, or perhaps from occasional counting errors.

$\mathrm{WI}_{1}$ larvae had higher survival under northern than southern conditions at both high RH (Kolmogorov-Smirnov test, 1-tailed, $n_{N}=46, n_{S}=48, D=0.309, \chi^{2}=8.94, \mathrm{df}=2$, $\boldsymbol{p}<0.025)$ and low RH $\left(n_{N}=38, n_{S}=30, \boldsymbol{D}=0.333, \chi^{2}=\right.$ 7.478, $\boldsymbol{p}<0.025)$. Similarly, SC larvae had higher survival under northern than southern conditions at high $\mathrm{RH}\left(n_{N}=\right.$ $\left.51, n_{S}=37, \boldsymbol{D}=0.430, \chi^{2}=15.849, \boldsymbol{p}<0.001\right)$. The direction of the difference was the same at low RH (Figure 1), but was not significant $\left(n_{N}=33, n_{S}=39, D=0.238, \chi^{2}=4.033\right.$,

Table 1 Daytime physical conditions in treatment chambers; experiment 1

\begin{tabular}{|c|c|c|c|c|c|c|c|c|c|c|c|c|}
\hline & \multicolumn{6}{|c|}{ Northern conditions } & \multicolumn{6}{|c|}{ Southern conditions } \\
\hline & \multicolumn{2}{|c|}{ High RH } & \multirow[b]{2}{*}{$\mathbf{N}$} & \multicolumn{2}{|c|}{ Low RH } & \multirow[b]{2}{*}{$\mathbf{N}$} & \multicolumn{2}{|c|}{ High RH } & \multirow[b]{2}{*}{$\mathbf{N}$} & \multicolumn{2}{|c|}{ Low RH } & \multirow[b]{2}{*}{$\mathbf{N}$} \\
\hline & Mean & SE & & Mean & SE & & Mean & SE & & Mean & SE & \\
\hline \multicolumn{13}{|l|}{ Larvae } \\
\hline Temp $\left({ }^{\circ} \mathrm{C}\right)$ & 22.87 & 0.130 & 14 & 22.41 & 0.051 & 14 & 32.80 & 0.118 & 14 & 34.39 & 0.396 & 14 \\
\hline $\mathrm{RH}(\%)$ & 90.20 & 0.442 & 10 & 75.14 & 0.417 & 14 & 91.57 & 2.021 & 14 & 72.57 & 0.768 & 14 \\
\hline \multicolumn{13}{|l|}{ Nymphs } \\
\hline Temp $\left({ }^{\circ} \mathrm{C}\right)$ & 18.85 & 0.085 & 16 & 18.76 & 0.084 & 16 & 34.83 & 0.112 & 16 & 34.81 & 0.073 & 16 \\
\hline RH (\%) & 93.56 & 0.302 & 16 & 71.94 & 0.924 & 16 & 91.88 & 0.935 & 16 & 72.93 & 0.497 & 14 \\
\hline
\end{tabular}


$\boldsymbol{p}>0.1)$. Thus, survival was generally higher for both clades under northern than under southern conditions.

Nymphs. Daytime humidity averaged about 93\% in the high $\mathrm{RH}$ chambers and $72 \%$ in the low $\mathrm{RH}$ chambers (Table 1). Survival did not differ significantly between $\mathrm{WI}_{1}$ and $\mathrm{SC}$ nymphs under conditions of high $\mathrm{RH}$ (Kolmogorov-Smirnov Test, 2-tailed, $n_{A 1}=109, n_{S 1}=87$, $\boldsymbol{D}=0.051, \boldsymbol{p}>0.1)$. However, overall survival of the two clades differed under conditions of low RH $\left(n_{A 1}=97\right.$, $n_{S 1}=87, \quad \boldsymbol{D}=0.223, \quad \mathrm{p}<0.05$ ) (Figure 2). Therefore, nymphal survival was high for both clades under both northern and southern conditions when $\mathrm{RH}$ was high, and clades differed in survival only when $\mathrm{RH}$ was low. $\boldsymbol{H}_{\boldsymbol{1}}$ is rejected, because survival of SC nymphs was not greater than that of $\mathrm{WI}_{1}$ under southern conditions (Figure 2). In fact, $\mathrm{WI}_{1}$ nymphal survival was significantly greater overall than that of SC under low RH conditions (KolmogorovSmirnov test, one-tailed, $\left.\chi^{2}=9.117, \boldsymbol{p}<0.005\right)$. Therefore nymphal survival did not differ consistently between clades at high $\mathrm{RH}$, but was similar to larval survival under low $\mathrm{RH}$, with $\mathrm{WI}_{1}$ showing significantly higher survival than SC nymphs.

Survival at low RH was not significantly greater under northern than under southern conditions for either the $\mathrm{WI}_{1}$ (Kolmogorov-Smirnov test, 1-tailed, $n_{N}=51, n_{S}=46$, $\left.\boldsymbol{D}=0.214, \chi^{2}=4.415, \mathrm{df}=2, \boldsymbol{p}>0.1\right)$ or the SC nymphs $\left(n_{N}=48, n_{S}=39, \boldsymbol{D}=0.220, \chi^{2}=4.149, \boldsymbol{p}>0.1\right)$. For both groups of nymphs, survival was similar under northern and southern conditions.

\section{Experiment 2}

Daytime temperatures were in the range of $22-23^{\circ} \mathrm{C}$ in the chambers simulating northern conditions and $32-33^{\circ} \mathrm{C}$ in the chambers simulating southern conditions. Daytime $\mathrm{RH}$ values were in the range of 93-96\% (Table 2). Substantial variability in survival was evident among larvae of different genotypes both within and between regions (Figure 3). The ANOVA model successfully predicted arcsine transformed proportions of larvae surviving $\left(\boldsymbol{R}^{2}=\right.$ 0.663, $\left.\boldsymbol{F}=26.87, \mathrm{df}_{1}=11, \mathrm{df}_{2}=150, \quad \boldsymbol{p}<0.0001\right)$, with

Nymphs - High RH

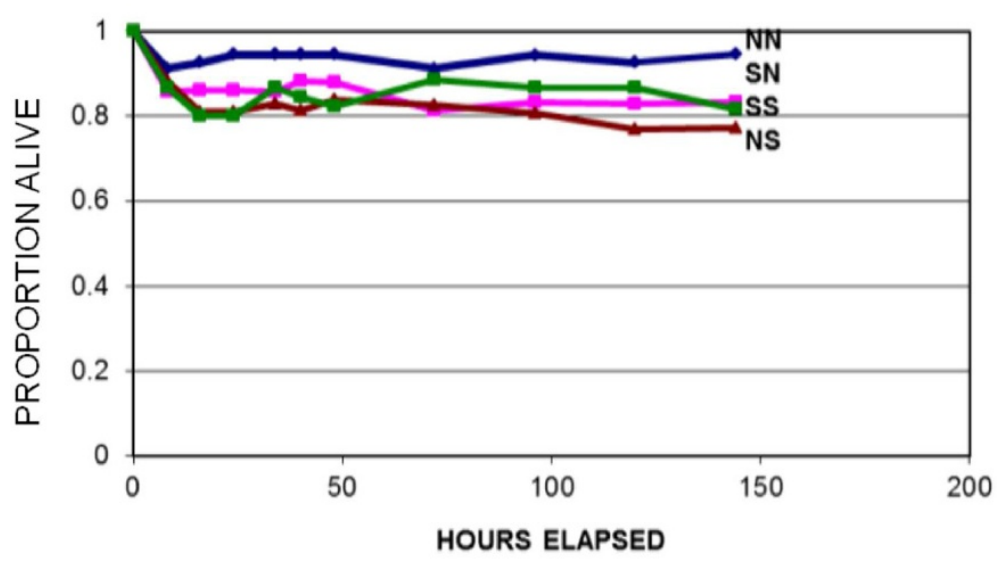

Nymphs - Low RH

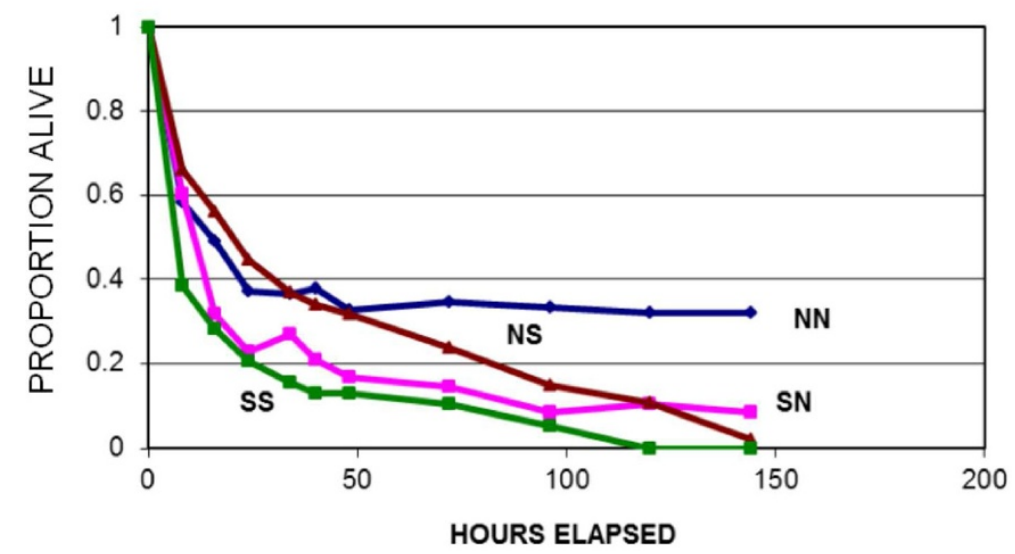

Figure 2 Survival of $I$. scapularis nymphs under conditions of high and low relative humidity. Labels as in Figure 1. 
Table 2 Daytime physical conditions in treatment chambers; experiment 2

\begin{tabular}{cccccccc}
\hline & \multicolumn{2}{c}{ Northern conditions } & & \multicolumn{3}{c}{ Southern conditions } \\
& Mean & SE & & N & Mean & SE & N \\
\hline GA larvae & & & & & & \\
Temp $\left({ }^{\circ} \mathrm{C}\right)$ & 22.34 & 0.031 & 35 & 32.38 & 0.077 & 35 \\
RH (\%) & 95.47 & 0.341 & 34 & 95.53 & 0.298 & 34 \\
WI \& MA larvae & & & & & & \\
Temp $\left({ }^{\circ} \mathrm{C}\right)$ & 22.69 & 0.174 & 36 & 32.79 & 0.087 & 36 \\
RH $(\%)$ & 94.03 & 0.647 & 36 & 93.67 & 0.434 & 36 \\
\hline
\end{tabular}

significant differences in larval survival among regions $\left(\boldsymbol{F}=68.31, \mathrm{df}_{1}=2, \mathrm{df}_{2}=150, \boldsymbol{p}<0.0001\right)$, and with greatest survival of $\mathrm{WI}_{2}$ larvae, but comparable survival of larvae from GA and MA (Figure 4). However, survival under northern vs. southern conditions showed a significant interaction with region of origin $\left(\boldsymbol{F}=5.16, \mathrm{df}_{1}=2, \mathrm{df}_{2}=\right.$ $150, \boldsymbol{p}<0.0068$ ), so we analyzed the regions separately using factorial ANOVA (N/S x clutch). Larvae from different mothers in each region differed significantly in overall survival (GA, $\boldsymbol{F}=23.78, \boldsymbol{p}<0.0001$; WI, $\boldsymbol{F}=8.15, \boldsymbol{p}<$ 0.0009; MA, $\boldsymbol{F}=24.57, \boldsymbol{p}<0.0001 ; \mathrm{df}_{1}=2, \mathrm{df}_{2}=48$ in all comparisons). Larvae from GA and MA showed higher survival under northern than under southern conditions
(GA, $\boldsymbol{F}=17.18, \mathrm{df}_{1}=1, \mathrm{df}_{2}=48, \boldsymbol{p}<0.0001 ; \mathrm{MA}, \boldsymbol{F}=54.94$, $\left.\mathrm{df}_{1}=1, \mathrm{df}_{2}=48, \boldsymbol{p}<0.0001\right)$. Survival under northern vs. southern conditions did not differ significantly for the larvae from WI $\left(\boldsymbol{F}=2.70, \mathrm{df}_{1}=1, \mathrm{df}_{2}=48, \boldsymbol{p}=0.1068\right)$, but the trend was in the same direction (Figure 4).

\section{Experiment 3}

Daytime temperatures were in the vicinity of $22-23^{\circ} \mathrm{C}$ in the chambers simulating northern conditions, and 32 $34^{\circ} \mathrm{C}$ in the chambers simulating southern conditions. Relative humidities ranged from $81-86 \%$ under northern conditions and $81-82 \%$ under southern conditions (Table 3). Survival varied substantially both among larvae from different mothers within regions, and among larvae from different regions (Figure 5). The ANOVA model successfully predicted arcsine transformed proportional survival $\left(\boldsymbol{R}^{2}=0.754, \boldsymbol{F}=43.87, \mathrm{df}_{1}=7, \mathrm{df}_{2}=100, \boldsymbol{p}<0.001\right)$. Survival differed among larvae from different mothers within regions $\left(\boldsymbol{F}=46.57, \mathrm{df}_{1}=4, \mathrm{df}_{2}=100, \boldsymbol{p}<0.0001\right)$, and overall between regions $\left(\boldsymbol{F}=83.18, \mathrm{df}_{1}=1, \mathrm{df}_{2}=100\right.$, $\boldsymbol{p}<0.0001$ ), with the FL larvae surviving longer than the MI larvae (Figure 6). Both FL and MI larvae survived longer under northern than under southern conditions $(\boldsymbol{F}=$ $\left.36.72, \mathrm{df}_{1}=1, \mathrm{df}_{2}=100, \boldsymbol{p}<0.0001\right)$. There was no interaction between effects of region of origin and north-south conditions $\left(\boldsymbol{F}=0.03, \mathrm{df}_{1}=1, \mathrm{df}_{2}=100, \boldsymbol{p}=0.339\right)$.

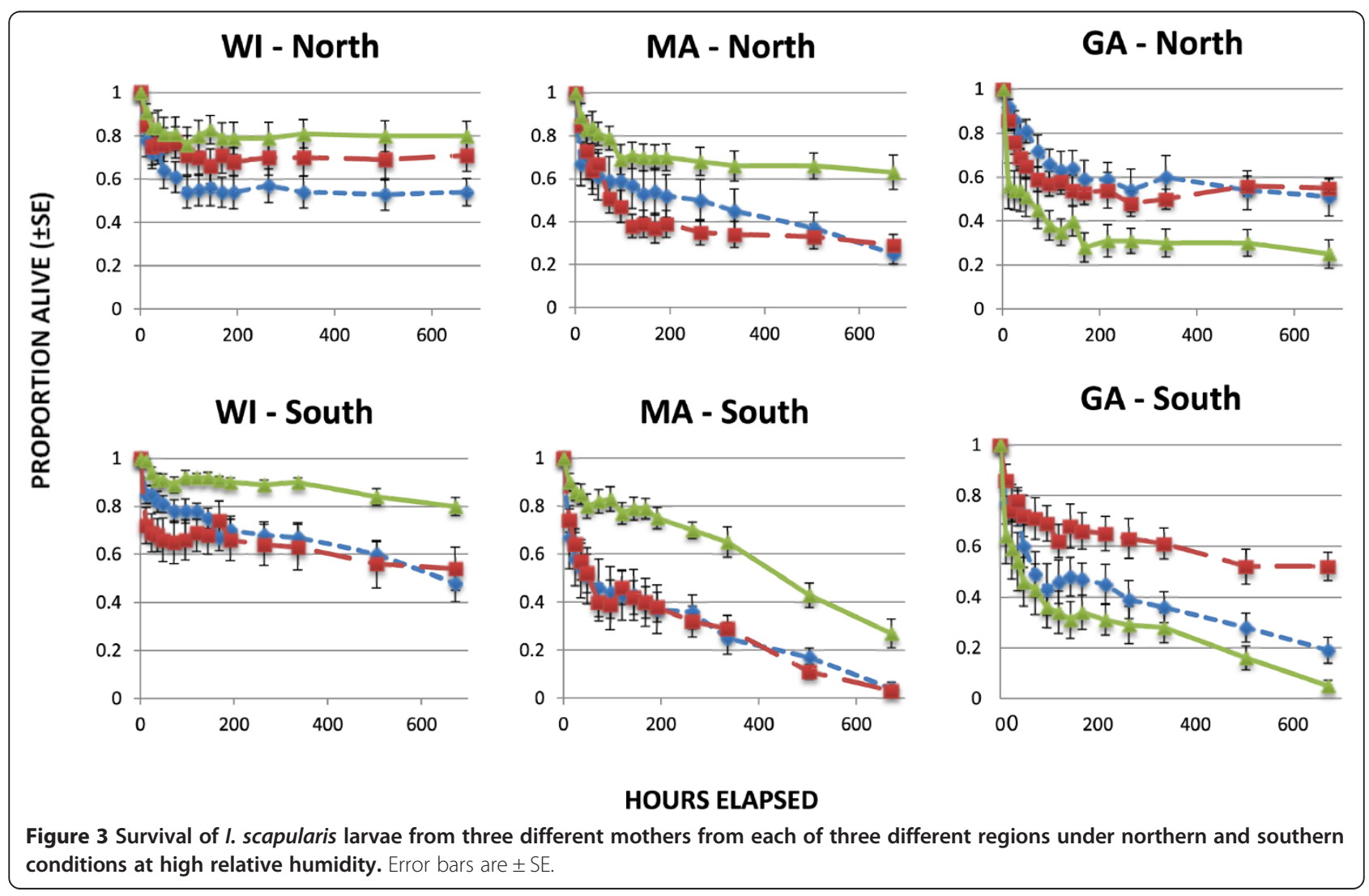




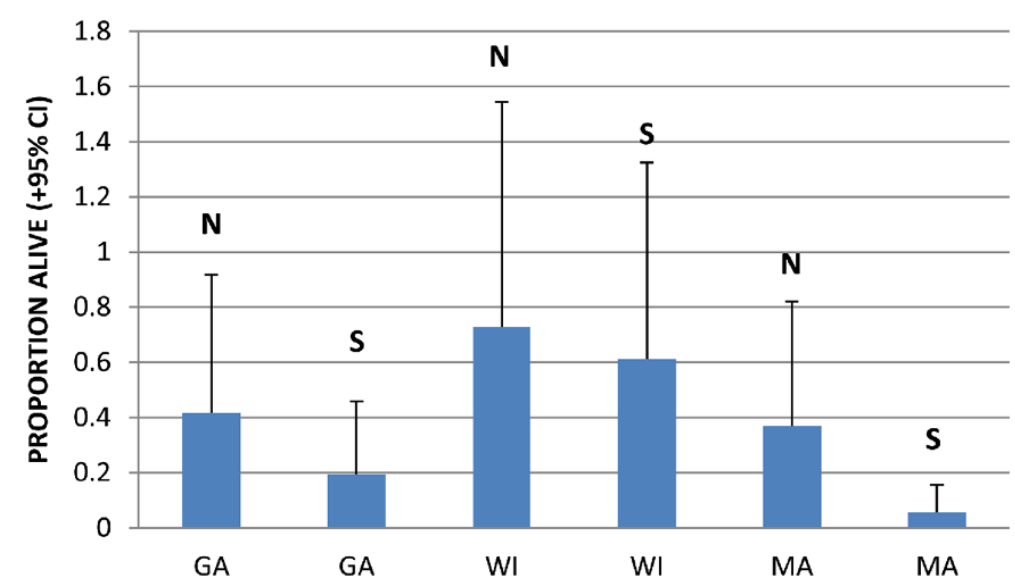

Figure 4 Mean proportion alive after 28 days ( $+95 \% \mathrm{Cl}$ ) of larvae from Georgia (GA), Wisconsin (WI), and Massachusetts (MA) under northern $(\mathrm{N})$ and southern $(\mathrm{S})$ conditions. Means backtransformed from arcsine transformed data.

\section{Discussion}

Our results demonstrate clear differences in survival patterns among larval Ixodes scapularis from different regions of the northern and southern U.S. These regional differences are substantial, despite considerable variability of survival patterns among larvae from different mothers within regions (Figures 3, 5). Interestingly, survival patterns did not show clear north-south trends. In controlled trials, ticks from both northern and southern parts of the U.S. showed long survival from some sites and relatively short survival from others. Wisconsin larvae survived longer than larvae from South Carolina and Georgia, but also longer than larvae from Massachusetts (which showed similar survival to the Georgia larvae). Larvae from Florida survived longer than larvae from Michigan. Clearly, there is no consistent north-south gradient in these results.

The one consistent result from all trials was that larvae tended to survive longer under northern conditions than they did under southern conditions. This was true of all tick populations tested, whether from the north or from the south (Figures 1, 4, 6). This might be expected because the warmer southern temperatures would be expected to increase desiccation, putting physiological

Table 3 Daytime physical conditions in treatment chambers; experiment 3

\begin{tabular}{|c|c|c|c|c|c|c|}
\hline & \multicolumn{2}{|c|}{ Northern conditions } & \multirow[b]{2}{*}{$\mathbf{N}$} & \multicolumn{2}{|c|}{ Southern conditions } & \multirow[b]{2}{*}{$\mathbf{N}$} \\
\hline & Mean & SE & & Mean & SE & \\
\hline \multicolumn{7}{|l|}{ FL larvae } \\
\hline Temp $\left({ }^{\circ} \mathrm{C}\right)$ & 22.60 & 0.044 & 36 & 32.59 & 0.026 & 36 \\
\hline RH (\%) & 81.61 & 0.341 & 36 & 81.92 & 0.352 & 36 \\
\hline \multicolumn{7}{|l|}{ Ml larvae } \\
\hline Temp $\left({ }^{\circ} \mathrm{C}\right)$ & 22.36 & 0.046 & 36 & 33.13 & 0.082 & 35 \\
\hline $\mathrm{RH}(\%)$ & 85.83 & 0.355 & 36 & 81.067 & 0.454 & 34 \\
\hline
\end{tabular}

stress on the larval ticks, and because physiological processes tend to be more rapid at higher temperatures. Nymphs, which are considerably larger than larvae and have lower surface area to volume ratios, showed less in the way of regional effects than did larvae (Figures 1 and 2). Nevertheless, the shorter survival of larvae under southern conditions suggests that the southern environment is less congenial for survival of I. scapularis than the north. Indeed, some studies have suggested that I. scapularis population densities in the south are lower than in the north $[22,23]$. Furthermore, this environmental difference could have imposed selective pressure on southern populations that has resulted in life cycle characteristics or behaviors in southern ticks that could influence pathogen transmission. For example, preliminary data suggest behavioral differences in southern compared to northern genotypes of $I$. scapularis that might influence host encounter and pathogen transmission (Kuczaj IM, Hickling GJ, Tsao JI, unpublished observations; presented at $13^{\text {th }}$ International Conference on Lyme Borreliosis and Other Tick-Borne Diseases, August 2013, Boston, MA). We hypothesize that the environmental differences between the north and the south have resulted in the evolution of adaptations in southern I. scapularis ticks that result in less transmission of Lyme spirochetes in southern environments. Further research will be needed to determine whether this hypothesis is correct, and what the relevant adaptations of southern $I$. scapularis populations might be.

The longer survival of Wisconsin compared to Massachusetts larvae in our study (Figure 4) suggests that there are ecologically important genetic differences between northeastern and north central populations of I. scapularis. These differences might be related to the necessity to survive harsher winter environments in the northern midwest than in the northeast. Gatewood et al. [24] described greater overlap of larval and nymphal phenologies in 


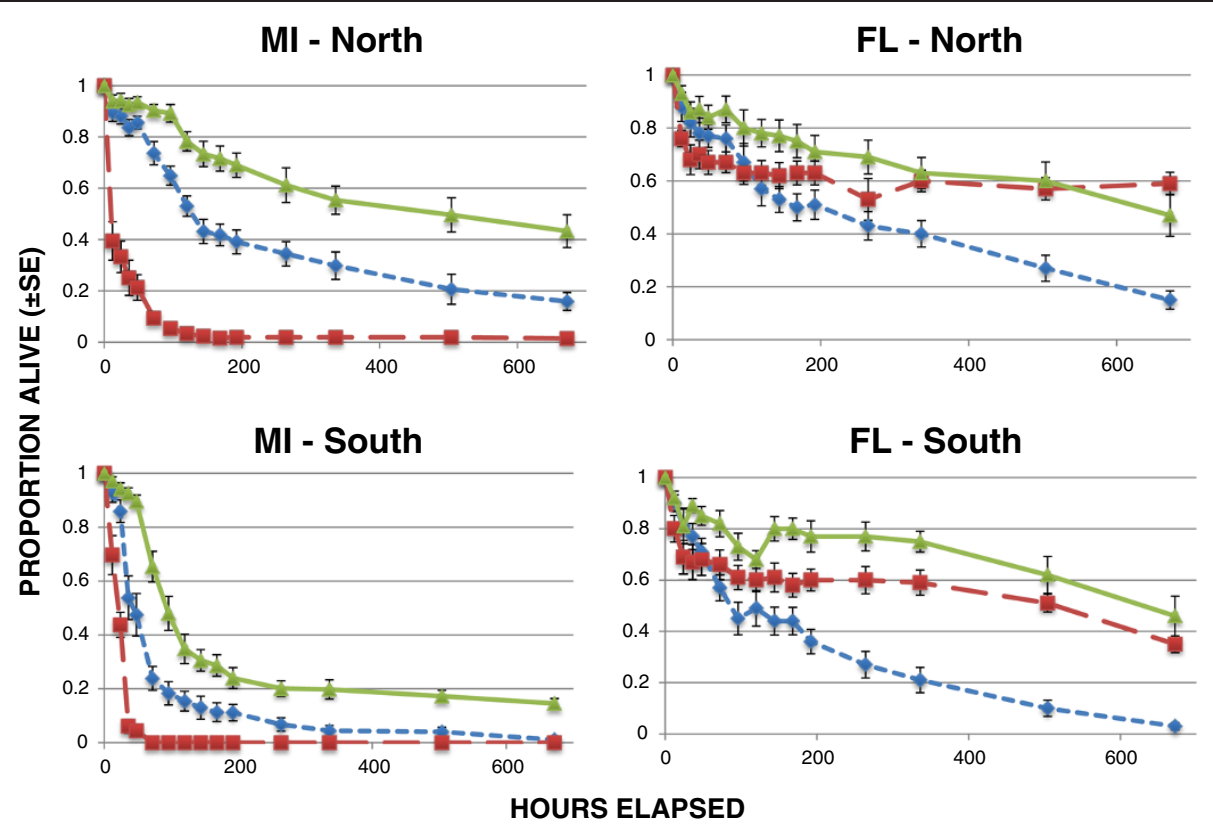

Figure 5 Survival of $I$. scapularis larvae from three different mothers from each of two different regions under northern and southern conditions at moderate relative humidity. Error bars are \pm SE.

midwestern compared to northeastern populations, and related those differences to climate variables and to maintenance of different strains of Borrelia burgdorferi in the tick populations. These different bacterial strains differ in virulence, suggesting possible implications for human disease. Our results suggest that northeastern I. scapularis differ genetically from north central genetic types, and that these differences might contribute to the patterns described by Gatewood et al. [24]. Studies of survival and of other characteristics of ticks from additional northeastern and north central sites would be needed to determine whether these differences are, in fact, regional in nature.

Some authors have argued that the differences in Lyme disease incidence between northern and southern states

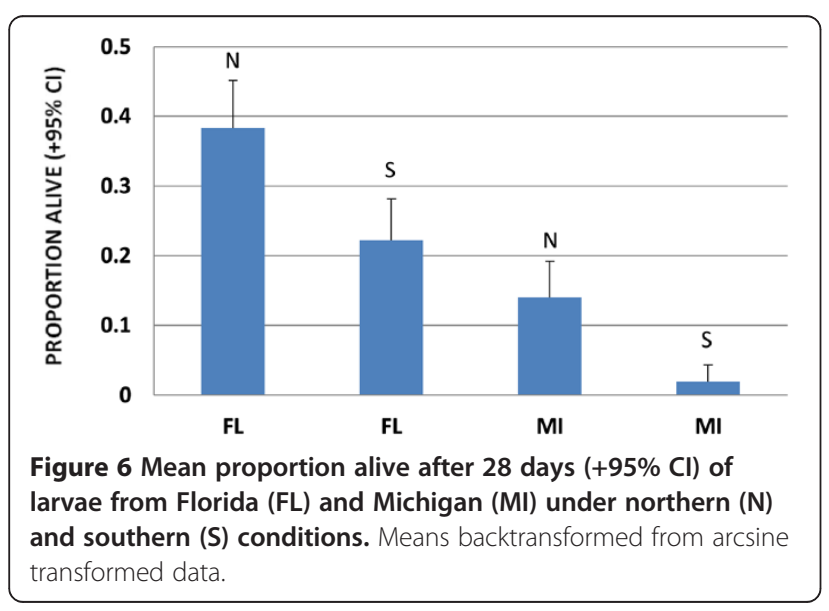

result from differences in host communities, including greater host species diversity in the south [25], and the presence of lizards in southern but not in northern sites $[2,26]$. Others have suggested differences in tick phenology, presumably resulting from the higher temperatures and longer growing season in the south [27], which might interfere with the efficient transmission cycle found in the north. Of course, these hypotheses are not mutually exclusive. Nevertheless, our results present an additional hypothesis. Perhaps southern conditions are generally less congenial than northern conditions for survival of $I$. scapularis, as was true for the larvae in our experiments. This could result in lower population densities in southern states [22,28], which in turn would result in fewer ticks per host animal, and possibly other ecological and behavioral differences that might affect pathogen transmission. For example, the relatively poor southern conditions could affect phenologies by shortening activity periods, or they could select for host-seeking behaviors that would result in less transmission of pathogens among hosts of I. scapularis, and less attachment of this tick species to humans [29]. The overall warmer temperatures in the south might simply produce a marginal environment for this tick species, resulting in a less efficient enzootic cycle. This phenomenon might contribute, along with the many other environmental differences between the north and south, to the observed geographical patterns in Lyme disease incidence.

Recent modeling studies have suggested that warmer conditions due to climate change might result in 
expansion of the distribution of Lyme disease into more northern latitudes [30,31]. Interestingly, our results suggest that these same environmental changes might result in less Lyme disease in the southern portions of its range. Clearly, additional studies of the behavioral, life history, and ecological differences between various genetic groups of I. scapularis are likely to provide insights into the geographical distribution of Lyme disease in North America.

\section{Conclusions}

Survival patterns differed among larval I. scapularis ticks from different regions in eastern and central USA. These patterns were characterized by significant differences in length of survival among larvae from different mothers within regions, and overall differences among larvae from different regions. These overall differences did not follow a simple north-south pattern, despite the published north-south patterns in tick genetics. Larvae from both northern and southern regions and at various relative humidities survived longer under northern conditions of temperature and diurnal period than under southern conditions. Thus, southern conditions are less favorable for larval survival, which might favor selection for ecological or behavioral adaptations that lower the level of pathogen transmission by I. scapularis to humans.

\section{Competing interests}

The authors state that they have no competing interests.

\section{Authors' contributions}

HSG and ELR conceived and designed the project, performed much of the experimental setup and mortality reading, and analyzed the results. AA and RAL contributed to experimental design and helped with experimental setup and readings. GCP, IMK and JIT established and maintained the tick colonies and supplied specimens for the experiments. All authors contributed to interpretation of results, co-revised the manuscript, and approved the final version.

\section{Acknowledgments \\ The authors thank E. Hofmeister, G. Hickling, and R. Burke for constructive comments on early drafts of the manuscript. F. Mackechnie and M. MacKenzie assisted with experimental setup and observations. Use of trade or product names does not imply endorsement by the U.S. Government. This work was supported by National Science Foundation EID award EF-0914476, by the University of Rhode Island, and by the U.S. Geological Survey.}

\section{Author details}

'USGS Patuxent Wildlife Research Center, RI Field Station, Woodward Hall PSE, University of Rhode Island, Kingston, RI 02881, USA. ${ }^{2}$ Department of Plant Sciences and Entomology, Woodward Hall, University of Rhode Island, Kingston, RI 02881, USA. ${ }^{3}$ Current address: Caesar Kleberg Wildlife Research Institute, Texas A\&M University-Kingsville, Kingsville, TX 78363, USA. ${ }^{4}$ Department of Fisheries and Wildlife, Michigan State University, East Lansing, MI 48824, USA.

Received: 12 June 2014 Accepted: 19 August 2014 Published: 26 August 2014

\section{References}

1. $[C D C]$ Centers for Disease Control and Prevention: Summary of notifiable diseases - United States, 2010. MMWR Morb Mortal Wkly Rep 2012, 59(53):1-111.
2. Dennis DT, Nekomoto TS, Victor JC, Paul WS, Piesman J: Reported distribution of Ixodes scapularis and Ixodes pacificus (Acari: Ixodidae) in the United States. J Med Entomol 1998, 35:628-629.

3. Brownstein JS, Holford TR, Fish D: A climate-based model predicts the spatial distribution of the Lyme disease vector /xodes scapularis in the United States. Environ Health Persp 2003, 111:1152-1157.

4. Norris DE, Klompen JSH, Kierans JE, Black WC: Population genetics of Ixodes scapularis (Acari: Ixodidae) based on mitochondrial $16 \mathrm{~S}$ and $12 \mathrm{~S}$ genes. J Med Entomol 1996, 33:78-89.

5. Rich SM, Caporale DA, Telford SR, Kocher TD, Hartl DL, Spielman A: Distribution of the Ixodes ricinus-like ticks of eastern North America. Proc Natl Acad Sci 1995, 92:6284-6288.

6. Chan CTW: Comparative Analysis of Microsatellite and Mitochondrial Genetic Variation in Ixodes Scapularis, MS thesis. Georgia Southern University, Department of Biology; 2012.

7. Qiu W-G, Dykhuizen DE, Acosta MS, Luft BJ: Geographic uniformity of the Lyme disease spirochete (Borrelia burgdorferi) and its shared history with tick vector (Ixodes scapularis) in the northeastern United States. Genetics 2002, 160:833-849.

8. Humphrey PT, Caporale DA, Brisson D: Uncoordinated phylogeography of Borrelia burgdorferi and its tick vector, Ixodes scapularis. Evolution 2010, 64:2653-2663.

9. Spielman A, Telford SR, Pollack RJ: The Origins and Course of the Present Outbreak of Lyme Disease. In Ecology and Environmental Management of Lyme Disease. Edited by Ginsberg HS. New Brunswick, New Jersey: Rutgers University Press; 1993:83-96.

10. Knülle W: Equilibrium humidities and survival of some tick larvae. J Med Entomol 1966, 2:335-338.

11. Needham GR, Teel PD: Off-host physiological ecology of ixodid ticks. Annu Rev Entomol 1991, 36:659-681.

12. Daniel M, Dusbábek F: Micrometeorological and Microhabitat Factors affecting maintenance and dissemination of Tick-Borne Diseases in the Environment. In Ecological Dynamics of Tick-Borne Zoonoses. Edited by Sonenshine DE, Mather TN. New York: Oxford University Press; 1994:91-138.

13. Stafford KC: Survival of immature Ixodes scapularis (Acari: Ixodidae) at different relative humidities. J Med Entomol 1994, 31:310-314.

14. Rodgers SE, Zolnik CP, Mather TN: Duration of exposure to suboptimal atmospheric moisture affects nymphal blacklegged tick survival. $J$ Med Entomol 2007, 44:372-375.

15. Sonenshine DE: Biology of Ticks, Volume 1. NY: Oxford University Press; 1991.

16. Ginsberg HS, Zhioua E: Nymphal survival and habvitat distribution of Ixodes scapularis and Amblyomma americanum ticks (Acari: Ixodidae) on Fire Island, New York, USA. Exp Appl Acarol 1996, 20:533-544.

17. Bertrand MR, Wilson ML: Microclimate-dependent survival of unfed adult Ixodes scapularis (Acari: Ixodidae) in nature: life cycle and study design implications. J Med Entomol 1996, 33:619-627.

18. Vail SG, Smith G: Air temperature and relative humidity effects on behavioral activity of blacklegged tick (Acari: Ixodidae) nymphs in New Jersey. J Med Entomol 1998, 35:1025-1028.

19. Vail SG, Smith G: Vertical movement and posture of blacklegged tick (Acari: Ixodidae) nymphs as a function of temperature and relative humidity in laboratory experiments. J Med Entomol 2002, 39:842-846.

20. Winston PW, Bates DH: Saturated solutions for the control of humidity in biological research. Ecology 1960, 41:232-237.

21. Siegal S: Nonparametric Statistics for the Behavioral Sciences. NY: McGraw-Hill; 1956.

22. Diuk-Wasser MA, Gatewood AG, Cortinas MR, Yaremych-Hamer S, Tsao J, Kitron U, Hickling G, Brownstein JS, Walker E, Piesman J, Fish D: Spatiotemporal patterns of host-seeking Ixodes scapularis nymphs (Acari: Ixodidae) in the United States. J Med Entomol 2006, 43:166-176.

23. Diuk-Wasser MA, Hoen AG, Cislo P, Brinkerhoff $R$, Hamer $S A$, Rowland $M$, Cortinas R, Vourc'h G, Melton F, Hickling GJ, Tsao Jl, Bunikis J, Barbour AG, Kitron U, Piesman J, Fish D: Human risk of infection with Borrelia burgdorferi, the Lyme disease agent, in eastern United States. Am J Trop Med Hyg 2012, 86:320-327.

24. Gatewood AG, Liebman KA, Vourc'h G, Bunikis J, Hamer SA, Cortinas R, Melton F, Cislo P, Kitron U, Tsao J, Barbour AG, Fish D, Diuk-Wasser MA: Climate and tick seasonality are predictors of Borrelia burgdorferi genotype distribution. Appl Environ Microbiol 2009, 75:2476-2483.

25. Ostfeld RS, Keesing F: Biodiversity and disease risk: the case of Lyme disease. Conserv Biol 2000, 14:722-728. 
26. Apperson CS, Levine JF, Evans TL, Braswell A, Heller J: Relative utilization of reptiles and rodents as hosts by immature Ixodes scapularis (Acari: Ixodidae) in the coastal plain of North Carolina, USA. Exp Appl Acarol 1993, 17:719-731.

27. Ogden NH, Lindsay LR, Beauchamp Charron GD, Maarouf A, O'Callaghan CJ, Waltner-Toews D, Barker IK: Investigation of relationships between temperature and developmental rates of tick Ixodes scapularis (Acari: Ixodidae) in the laboratory and field. J Med Entomol 2004, 41:622-633.

28. Diuk-Wasser MA, Vourc'h G, Cislo P, Hoen AG, Melton F, Hamer SA, Rowland M, Cortinas R, Hickling GJ, Tsao Jl, Barbour A, Kitron U, Piesman J, Fish D: Field and climate-based model for predicting the density of hostseeking nymphal Ixodes scapularis, and important vector of tick-borne disease agents in the eastern United States. Global Ecol Biogeogr 2010, 19:504-514

29. Stromdahl EY, Hickling GJ: Beyond Lyme: aetiology of tick-borne human diseases with emphasis on the south-eastern United States. Zoonoses Public Health 2012, 59(Suppl. 2):48-64.

30. Brownstein JS, Holford TR, Fish D: Effect of climate change on Lyme disease risk in North America. Ecohealth 2005, 2:38-46.

31. Ogden NJ, Radojevic M, Wu X, Durvuri VR, Leighton PA, Wu J: Estimated effects of projected climate change on the basic reproductive number of the Lyme disease vector Ixodes scapularis. Environ Health Persp 2014, 122:631-638.

doi:10.1186/1756-3305-7-394

Cite this article as: Ginsberg et al:: Comparison of survival patterns of northern and southern genotypes of the North American tick Ixodes scapularis (Acari: Ixodidae) under northern and southern conditions.

Parasites \& Vectors 2014 7:394.

\section{Submit your next manuscript to BioMed Central and take full advantage of:}

- Convenient online submission

- Thorough peer review

- No space constraints or color figure charges

- Immediate publication on acceptance

- Inclusion in PubMed, CAS, Scopus and Google Scholar

- Research which is freely available for redistribution 